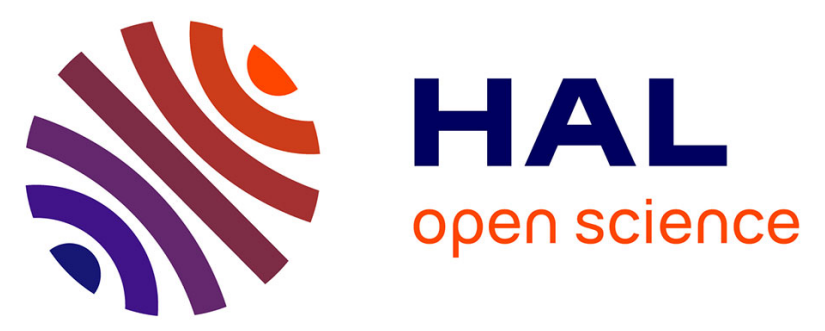

\title{
A comparative study of conventional activated sludge and fixed bed hybrid biological reactor for oilfield produced water treatment: influence of hydraulic retention time
}

Nicolas Lusinier, Isabelle Seyssiecq, Cecilia Sambusiti, Matthieu Jacob, Nicolas Lesage, Nicolas Roche

\section{To cite this version:}

Nicolas Lusinier, Isabelle Seyssiecq, Cecilia Sambusiti, Matthieu Jacob, Nicolas Lesage, et al.. A comparative study of conventional activated sludge and fixed bed hybrid biological reactor for oilfield produced water treatment: influence of hydraulic retention time. Chemical Engineering Journal, 2020, pp.127611. 10.1016/j.cej.2020.127611 . hal-02989059

\section{HAL Id: hal-02989059 \\ https://hal-amu.archives-ouvertes.fr/hal-02989059}

Submitted on 18 Feb 2021

HAL is a multi-disciplinary open access archive for the deposit and dissemination of scientific research documents, whether they are published or not. The documents may come from teaching and research institutions in France or abroad, or from public or private research centers.
L'archive ouverte pluridisciplinaire HAL, est destinée au dépôt et à la diffusion de documents scientifiques de niveau recherche, publiés ou non, émanant des établissements d'enseignement et de recherche français ou étrangers, des laboratoires publics ou privés.

\section{(1) $(1) \Theta$}

Distributed under a Creative Commons Attribution - NonCommercial - NoDerivatives 44.0 
A comparative study of conventional activated sludge and fixed bed hybrid biological reactor for oilfield produced water treatment: influence of hydraulic retention time

Nicolas Lusinier ${ }^{1}$, Isabelle Seyssiecq ${ }^{2}$, Cecilia Sambusiti ${ }^{3}$, Matthieu Jacob $^{3}$, Nicolas Lesage $^{4}$, Nicolas Roche ${ }^{1^{*}}$

1: Aix Marseille Univ, CNRS, IRD, INRAE, Coll France, CEREGE, Aix en Provence, France

2: Aix Marseille Univ, CNRS, Centrale Marseille, M2P2, Marseille, France

3: Total SA, PERL - Pôle d'Etudes et de recherche de Lacq, Pôle Economique 2, BP 47 - RD 817, 64170 Lacq, France

4: Total SA, CSTJF, Avenue Larribau, 64000 Pau, France

Corresponding author: nicolas.roche@univ-amu.fr

\section{Abstract}

This study focuses on the development of a hybrid biological reactor for the treatment of synthetic oilfield produced water. To face increasingly strict regulations concerning produced water discharge, a fixed bed hybrid biological reactor (FBHBR) containing a combination of free activated sludge and a fixed biofilm support was compared to a conventional activated sludge reactor (CAS). After gradual microbial acclimation, a 133-day experiment showed that both bioreactors were able to efficiently remove phenol, toluene, xylenes, and polycyclic aromatic hydrocarbons (PAHs) from a synthetic wastewater with a chemical oxygen demand (COD) removal rate above $95 \%$, at hydraulic retention times (HRT) of $24 \mathrm{~h}$ and $18 \mathrm{~h}$, and that only the FBHBR was able to maintain high removal efficiency at an HRT of $12 \mathrm{~h}$. Ecotoxicity tests showed that outlet waters from both bioreactors were non-toxic. Assessment of the bacterial population revealed notable differences between the CAS reactor and 
FBHBR. In particular, wider diversity was observed in the FBHBR. The marked similarity between the bacterial composition of the free sludge and that of the biofilm in the FBHBR suggests that biofilm detachment played an important part role in bacterial development in the free sludge.

\section{Keywords}

Conventional activated sludge, fixed bed hybrid biological reactor, oilfield produced water treatment, hydraulic retention time

\section{Abbreviations $^{1}$}

\section{Introduction}

Oilfield-produced water (PW) is a wastewater stream generated during crude oil and gas extraction. It is basically composed of water originating from oil or gas reservoirs and crude processing. The PW flowrate increases with reservoir ageing. This increase is measured by the water to oil ratio (WOR) and represents the volume of PW to be managed per volume of crude oil. Currently, the average WOR ratio is 3:1 [1]. Because of the aging of most oil reservoirs, this ratio is expected to increase [2]. PW composition is also site specific and depends on several factors, including the geological properties of the reservoir or even the composition of the crude oil and gas in contact with the water [3]. Basically, three families of compounds are found in PW: (1) organic compounds including dissolved and dispersed hydrocarbons (aliphatic hydrocarbons, carboxylic acids, benzene, toluene, ethylbenzene, xylene (BTEX), polycyclic aromatic hydrocarbons (PAHs), phenols, heavy alkylphenols, heavy

\footnotetext{
1 BAF: Biological Aerated Filter, BTEX: Benzene, Toluene, Ethylbenzene and Xylene, CAS: Conventional Activated Sludge, COD: Chemical Oxygen Demand, DO: Dissolved Oxygen, EPA: Environmental Protection Agency, FBHBR: Fixed Bed Hybrid Biological Reactor, HRT: Hydraulic Retention Time, MBBR: Moving Bed Biofilm Reactor, MBR: Membrane Bioreactor, OLR: Organic Loading Rate, PAH: Poly Aromatic Hydrocarbon, PNEC: Predicted No Effect Concentration, PW: Produced Water, TN: Total Nitrogen, TSS: Total Suspended Solids, TOC: Total Organic Carbon, VOC: Volatile Organic Compounds, VSS: Volatile Suspended Solids, WOR: Water to Oil Ratio
} 
hydrocarbons), (2) inorganic compounds i.e. dissolved anions and cations that contribute to the salinity of PW, trace metals (iron, chromium, lead, mercury, cadmium, copper, zinc and silver) and naturally occurring radioactive materials, and (3) production chemicals (corrosion inhibitors, biocides, emulsion breakers, asphaltene inhibitor, $\mathrm{H}_{2} \mathrm{~S}$ scavengers, etc.) that are used to insure the oil is extracted properly [4]-[7]. Both the increasing amount of PW and its complex composition are raising new concerns and leading to new investigations of PW treatment and discharge.

Today, there is a change in the perception of PWs, which are now considered as a valuable resource, especially for reinjection in oil reservoirs, to reduce overall water consumption in water-stressed regions. Each water use requires that specific water quality standards be met, including the removal of dispersed phases before water reinjection and the removal of dissolved matter before discharge or reuse for irrigation. PW reinjection into oil producing reservoir enhances oil recovery, but requires treatment before reinjection to limit reservoir plugging and to insure longterm sustainable oil productivity in the long term [8]. Today, PW reinjection is a common practice in onshore fields: $98 \%$ of onshore $\mathrm{PW}$ is reported to be reinjected in oil formations, whereas, in the USA, only $9 \%$ of offshore PWs are reinjected [9]. Increasing this ratio is an objective for Total, but this requires more efficient polishing processes at water treatment units (membranes, media filters, centrifuges, etc.) which is mainly challenging offshore. Additionally, regulations concerning PW discharge are becoming increasingly strict. The regulations are site specific and depend on the location of the production asset. For instance, the Convention for the Protection of the Marine Environment of the North-East Atlantic, (OSPAR) recommends PW discharge limits in the North Sea [10]. OSPAR set the average 
maximum discharge limit for dispersed oil at $30 \mathrm{mg}^{-\mathrm{L}^{-1}}$ whereas the United States EPA set their value at $29 \mathrm{mg} \cdot \mathrm{L}^{-1}$ and a daily maximum discharge limit of $42 \mathrm{mg} \cdot \mathrm{L}^{-1}$ for oil and grease [11]. Recent regulations have also started to target dissolved organic compounds. To help oil producers deal with these new regulations, OSPAR recommendation 2014/5 produced a list of Predicted No Effect Concentrations (PNECs) for the most common dissolved organic compounds in PW [12]. Table 1 lists PNECs for the BTEX and PAHs found in PW.

Table 1. Summary of PNECs for BTEX and common PAHs in PW [12]

\begin{tabular}{cc}
\hline Compound & PNEC $\left(\mu \mathrm{g} \cdot \mathrm{L}^{-1}\right)$ \\
\hline Benzene & 8 \\
Toluene & 7.4 \\
Ethylbenzene & 10 \\
Xylene & 8 \\
\hline Naphthalene & 2 \\
Anthracene & 0.1 \\
Phenanthrene & 1.3 \\
Benzo[a]pyrene & 0.00017 \\
Fluorene & 0.25 \\
Phenols (and $\mathrm{C}_{1-3}$ alkylphenols) & 7.7 \\
\hline
\end{tabular}

Treatment processes thus have to be strengthened and adapted to these new directives. PW treatments are usually physical-chemical processes [13]. Current treatments aim to remove dispersed hydrocarbons from PW to comply with existing recommendations, but these techniques do not remove dissolved hydrocarbons and 
are not efficient enough to comply with the new recommendations. Furthermore, the physical-chemical processes, such as oxidation, used to treat dissolved hydrocarbons can produce potentially toxic by-products. Recent research has focused on biological treatments [14]-[17]. In these processes, the water is treated by the action of a bacterial community in an aeration tank. The wastewater provides the required nutrients and food for biomass growth. Biological treatment appears to be a viable alternative to physical-chemical processes as operating costs are lower, and the processes are eco-friendly [18], [19]. However, to date, research on the biological treatment of PW has been limited. Some studies used technologies such as conventional activated sludge (CAS) reactors, biological aerated filters (BAF), or membrane bioreactors (MBR) and reported good removal efficiency [18]-[22], but the influence of critical operating parameters such as hydraulic retention time (HRT) has not been studied in detail. This parameter is extremely important and must be as short as possible (without affecting COD removal efficiencies) to allow the treatment of high volumetric flowrates of PW in a minimum volume reactor to limit the process footprint particularly in offshore operations.

To meet this challenge, hybrid processes could have certain advantages over standard ones. Hybrid technologies, generally described as the combination of two or more treatment processes in one reactor, have produced promising results. For instance, combining different biological processes to remove recalcitrant compounds may be more efficient due to synergistic effects [23]. In this category of new processes, attention should be paid to fixed bed hybrid biological reactors (FBHBR). The FBHBR process, in which free biomass (activated sludge) and fixed biomass (biofilm) are combined in the same bioreactor, has attractive features among which higher concentrations of biomass can be achieved than with conventional 
technologies. For the same concentration of biomass (i.e. biofilm and suspended sludge), the FBHBR leaves a smaller footprint than a CAS reactor, thus reducing the size of treatment plant [24], [25]. For this reason, this process should be of particular interest for offshore implementations. Furthermore, the simultaneous presence of activated sludge and biofilm significantly increases bacterial biodiversity in the hybrid biological reactor, which in turn, should improve the removal of poorly biodegradable compounds. Biofilms are also more resistant to toxic compounds than free biomass thanks to their gel-like structure. The extracellular matrix secreted by the biofilm reinforces the diffusion barrier and limits contact between toxic compounds and bacteria [26]. FBHBRs have also been proved to be mass transfer efficient [27], [28]. While studying oxygen transfer in a hybrid membrane bioreactor in several model fluids, Zerari et al. [28] observed an up to $46 \%$ increase in the oxygen transfer coefficient with the presence of packing (for biofilm growth) compared to an empty reactor. This underlines the mechanical role played by the packing material in limiting the bubble coalescence that can occur in free sludge processes. This type of bioreactor has already proven its efficiency in domestic wastewater treatment [29]. Dong et al. [30] reported that adding modified ceramic biocarriers in a moving bed biofilm reactor (MBBR) for PW treatment enhanced removal performances and allowed better resistance to loading shocks by the bioreactor. Up to now, few studies have reported the use of FBHBRs for PW treatment. In a FBHBR, and with identical packing material, biofilm growth should be greater as there would be no shear stress on the carriers, which do not detach the biofilm, thus avoiding detachment of the film from their external surface, and the extensive development of biofilm would improve the performance of the bioreactor. Further, assessing the bacterial population is a good way to understand the behavior of such bioreactors and to what extent they 
differ from conventional technologies. Huang et al. [31] used a FBHBR to treat oil sands process-affected water and characterized the microbial population in their bioreactor. Their results showed that biofilm growth was associated with high microbial diversity.

The aim of this work was to use a FBHBR to treat PW to demonstrate the advantages of a hybrid technology for the treatment of industrial wastewater in a compact bioreactor compared to a conventional biological process. The process comprised a biological reactor containing a combination of activated sludge and a fixed biofilm. Particular attention was paid to reducing the HRT to identify the limits of CAS under reduced operating conditions.

\section{Materials and Methods}

\subsection{Experimental Setup}

The laboratory scale experimental device consisted in two Identical bioreactors made of cylindrical clear PVC columns (Figure 1a). The inner diameter of both bioreactors was $19 \mathrm{~cm}$, the total height was $107 \mathrm{~cm}$, and the working volume $30 \mathrm{~L}$. Figure $1 \mathrm{~b}$ is a schematic diagram of the experimental system. One bioreactor was configured as a CAS reactor and the other as a FBHBR. Cylindrical solid packing rings $\left(\right.$ AnoxKaldnes ${ }^{\circledR}$ ) were inserted in the column of the FBHBR to enable colonization by the biofilm. In the working volume $(30 \mathrm{~L}), 10 \mathrm{~L}$ was filled with the packing material, corresponding to a filling ratio of $33 \% \mathrm{v} / \mathrm{v}$, chosen based on the results of previous studies [28], [29]. The geometrical parameters of the packing material are listed in Table 2. To prevent the bed from moving, the packing rings were placed in a closed 7-mm stainless steel grid basket. The solid-liquid separation step was carried out in a $5 \mathrm{~L}$ gravity settler. The settled sludge was recirculated to the bioreactors by a 
peristaltic pump (Masterflex). The recirculation rate was set at $200 \%$ of the feed rate to prevent sludge from accumulating in the settlers. The synthetic PW was also fed into the bioreactor by a peristaltic pump (Masterflex). The feed rate was set as a function of the targeted HRT. Compressed air was supplied to the system through a porous membrane at the bottom of the column (Jäger). Air flowrates were measured

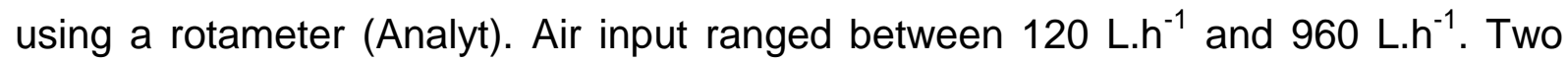
control valves were placed at the bottom of the column to prevent water entering the air supply system. 

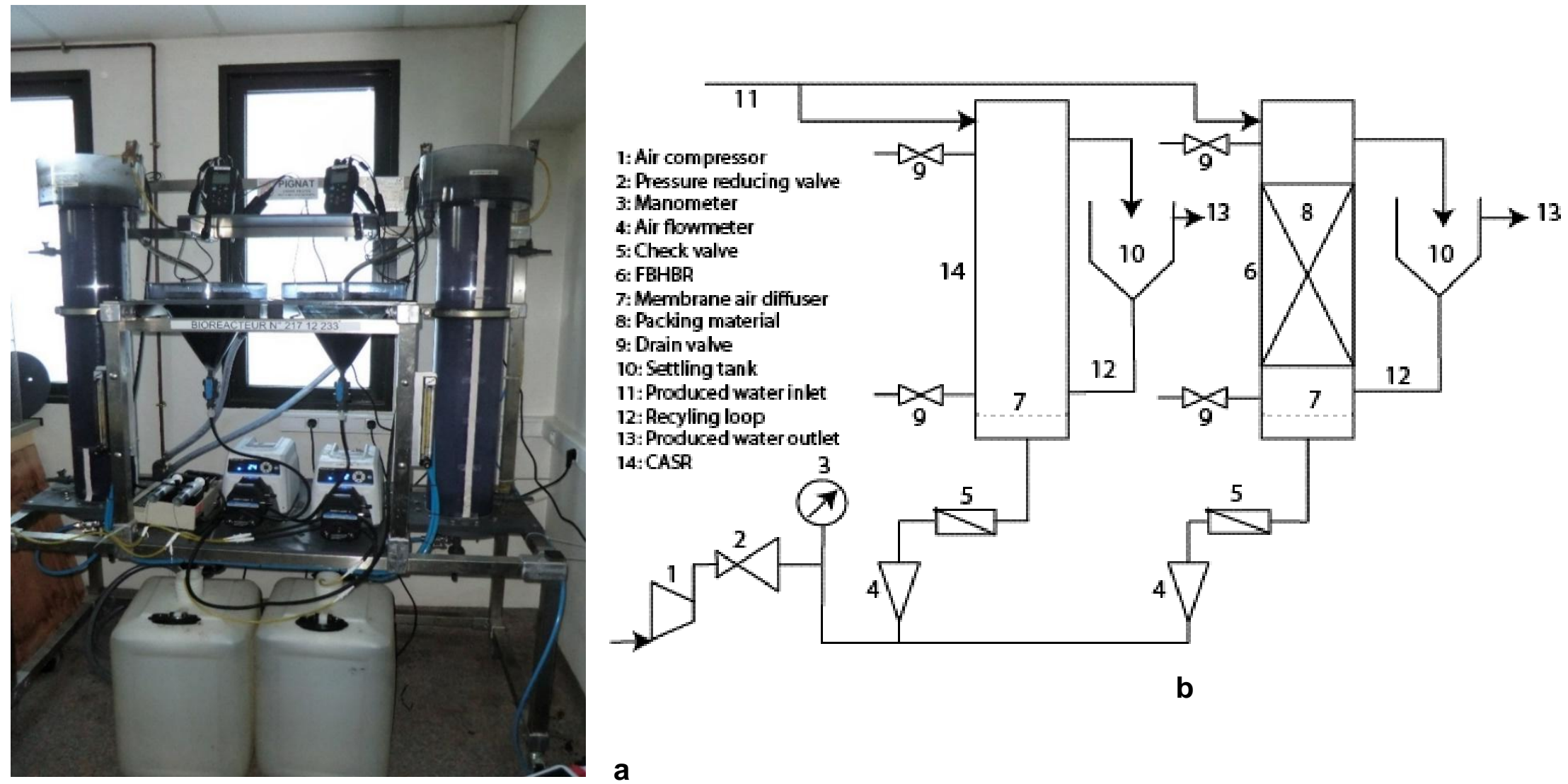

a

Figure 1. Laboratory pilot plants (CAS and FBHBR). (1a) photograph; (1b) schematic diagram of the experimental setup 


\section{Parameter}

Density $\rho_{\mathrm{s}}\left(\mathrm{kg} \cdot \mathrm{m}^{-3}\right)$

968

Diameter $d_{p}(\mathrm{~mm})$

Porosity $\varepsilon$

0.79

Specific area a $\left(\mathrm{m}^{-2} \cdot \mathrm{m}^{-3}\right)$

1,000

\subsection{Synthetic produced water}

The experiments were performed using a synthetic PW representative of a real PW. As the concentrations of targeted pollutants may be low to insure the viability of the biomass, dissolved organic compounds and nutrients were added to target values of Chemical Oxygen Demand (COD), Total Nitrogen (TN) and Total Phosphorous (TP) of $1600,20.6$, and $4 \mathrm{mg} \cdot \mathrm{L}^{-1}$ respectively. The detailed composition of the feed water is given in Table 3 . 


\section{Compound}

COD (adjusted with ethanol, sodium

acetate, urea, and peptone)

TOC

TN (from $\mathrm{NH}_{4} \mathrm{Cl}$, urea and peptone)

TP (from $\mathrm{KH}_{2} \mathrm{PO}_{4}$ )

Phenol

Toluene

o-Xylene

m-Xylene

Naphthalene

Phenanthrene

Benzo[a]pyrene

\section{Concentration (mg. $\left.\mathrm{L}^{-1}\right)$}

20.6

4

12

8

1

3

0.2

0.05

0.0002

\subsection{Microbial inoculum}

The activated sludge used to inoculate the bioreactors was taken from the activated sludge recycle line of a municipal wastewater treatment plant (Aix en Provence, France). The original concentration of total suspended sludge (TSS) was $4 \mathrm{~g} \cdot \mathrm{L}^{-1}$ in the two bioreactors. The biomass was slowly acclimated by gradually increasing the pollutant concentrations over a period of two months. To this end, the synthetic PW was diluted to reach $400 \mathrm{mg} \cdot \mathrm{L}^{-1}$ of COD for 8 days, $700 \mathrm{mg} \cdot \mathrm{L}^{-1}$ for 26 days and 1,000 mg. $\mathrm{L}^{-1}$ for 30 days. The sludge retention time (SRT) was set to a constant value of 20 days throughout the experiment (i.e. withdrawal of $1.5 \mathrm{~L}$ of free biomass from both bioreactors each day). It is important to note that acclimation ended when removal 
performances rose to satisfactory levels and when the biomass concentration stabilized, which corresponded to 6 times the SRT.

\subsection{Experimental Schedule}

When acclimation was complete, the 133-day experiment began. It was divided into four stages. Each stage consisted in a decrease in the HRT. Four HRTs were successively studied: $24,22,18$ and 12 hours. The concentrations of pollutants at the inlet were kept constant in each stage, leading to an increase in the organic loading rate $(\mathrm{OLR})$ with an increase in the feed flowrate. It is worth noting that the working volume (30 $\mathrm{L}$ in both CAS reactor and FBHBR) was included in the calculation of OLR. The values of these key parameters are summarized in Table 4. Each step lasted at least 20 days to overcome the SRT and was stopped once the bioreactors (or at least one of the two bioreactors) appeared to have reached steady state.

Table 4. Steps in the experimental bioreactors

\begin{tabular}{ccccc}
\hline Phase & I & II & III & IV \\
\hline Time (days) & $1-28$ & $28-58$ & $58-98$ & $98-133$ \\
HRT (h) & 24 & 22 & 18 & 12 \\
OLR $\left(\mathrm{kg}\right.$ cod $\cdot \mathrm{m}^{-}$ & 1.6 & 1.8 & 2.1 & 3.2 \\
$\left.{ }^{3} \cdot \mathrm{d}^{-1}\right)$ & & & \\
\hline
\end{tabular}

\subsection{Analytical methods}

\subsubsection{Measurement of the concentration of solids}

Concentrations of solids were determined in both bioreactors to quantify the amount of biomass over the whole experimental period. Free total suspended solids (TSS) and volatile suspended solids (VSS) were measured in both the CAS reactor and the 
FBHBR using standard methods [32]. In the FBHBR, the quantity of biofilm was assessed at end of the experimental period. The biofilm was weighed using an experimental procedure described elsewhere [33].

\subsubsection{Physical-chemical parameters}

The inlet and outlet water in the two bioreactors were monitored daily to calculate the efficiency of the treatment at each stage. Dissolved oxygen (DO) concentrations, $\mathrm{pH}$ and temperature in the two bioreactors were measured by oxygen electrodes (LDO10101, Hach, USA) and pH electrodes (PHC101, Hach, USA) connected to a Hach HQ40D digital multimeter ( Hach-Lange®, USA). All water samples were filtered using $0.45 \mu \mathrm{m}$ polyether sulfone filters before analysis. COD and phenol were analyzed by spectrophotometry using Hach DR6000 analytical kits. BTEX (toluene, m-xylene and o-xylene) were analyzed using a standardized chromatographic method (Headspace GC/MS) [34]. PAHs (naphthalene, phenanthrene, benzo[a]pyrene) were analyzed by gas chromatography coupled with mass spectrometry [35].

\subsubsection{Ecotoxicity measurements}

Ecotoxicity tests were performed to assess the potential toxicity of treated waters. Five samples were taken for each assessment, i.e. at the feed inlet, at the outlet of the CAS reactor at the end of stages III and IV, and at the outlet of the FBHBR at the end of stages III and IV. Standardized tests used were the Microtox (Vibrio fischeri) acute toxicity test [36], the freshwater algae (Pseudokirchneriella subcapitata) acute toxicity test [37], the Daphnia Magna acute toxicity test [38], and the Brachionus chronic toxicity test [39].

2.5.4 Characterization of the microbial population 
Changes in the microbial population in both the CAS bioreactor and FBHBR were investigated between the different key stages of the experiment: at the beginning of acclimation, at the 24-hour HRT equilibrium, the 18-hour HRT equilibrium and the 12hour HRT equilibrium. Sample preparation and analysis were performed at the INRAE Transfer Laboratory (Narbonne, France). The samples were stored at $-60{ }^{\circ} \mathrm{C}$ until DNA extraction. Extractions were performed using the DNEasy PowerSoil Kit (Qiagen). All ribosomal RNA genes were amplified by polymerase chain reaction through oligonucleotides targeting preserved regions common to all microorganisms. Sequencing was performed with a MiSeq sequencer (Illumina). Primers targeted the variable region V4-V5 of the $16 \mathrm{~S}$ rRNA ribosomal sequence. Data from the sequences were pretreated by the INRAE Transfer pipeline. Bioinformatic analysis of the sequence data enabled taxonomic identification of microorganisms (phylum and genus). Identification was based on the Greengenes taxonomy for bacteria/archaea. The analysis also enabled calculation of the Shannon-Weaver index representing biomass diversity: the higher the ecological index, the higher the biomass diversity.

\section{Results and discussion}

\subsection{Total suspended solids}

Figure 2a shows changes in free total suspended solids (TSS) concentrations in both bioreactors over time in all four experimental stages. The concentration of free sludge ranged from $1.4 \mathrm{~g} \cdot \mathrm{L}^{-1}$ at the beginning of the experiment in the two bioreactors to a maximum of $4.2 \mathrm{~g} . \mathrm{L}^{-1}$ in the FBHBR and of $3.8 \mathrm{~g} . \mathrm{L}^{-1}$ in the CAS bioreactor. A bulking phenomenon occurred in both bioreactors that explained the decrease in free TSS concentrations between day 29 and day 48. Consequently, fresh sludge was added in both bioreactors to increase TSS concentrations and led to higher values at day 49. TSS concentrations showed the same behavior from the end of stage II to stage 
$\mathrm{IV}$, with a value ranging from $1.4 \mathrm{~g} \cdot \mathrm{L}^{-1}$ to $4.2 \mathrm{~g} \cdot \mathrm{L}^{-1}$ in the FBHBR and from $1.2 \mathrm{~g} \cdot \mathrm{L}^{-1}$ to $3.8 \mathrm{~g} \cdot \mathrm{L}^{-1}$ in the CAS bioreactor. At the end of stage IV, TSS concentrations in the CAS reactor decreased significantly from $2.9 \mathrm{~g} \cdot \mathrm{L}^{-1}$ to $1.1 \mathrm{~g} \cdot \mathrm{L}^{-1}$.

Changes in free volatile suspended solids (VSS) followed the same trend as that of free TSS. In particular, calculation of the VSS/TSS ratio provided further information on the behavior of the biomass in both bioreactors. From stage I (HRT=24 h) to stage III $(H R T=18 \mathrm{~h})$, the mean ratio was 0.81 in the CAS reactor and 0.86 in the FBHBR. These high values, which are typical of synthetic wastewater, suggested good bacterial development in the two bioreactors and no accumulation of inert materials, as explained by Sambusiti et al. [21]. Interestingly, during the last stage of the process, different behaviors were observed in the CAS bioreactor and in the FBHBR. As shown in Figure 3 (HRT of $12 \mathrm{~h}$ ), the mean ratio remained constant in the FBHBR with a mean value of 0.83 , whereas in the CAS bioreactor, the concentration of free VSS decreased from $1.71 \mathrm{~g}^{-1} \mathrm{~L}^{-1}$ to $0.63 \mathrm{~g} \cdot \mathrm{L}^{-1}$, and the VSS/TSS ratio decreased from 0.82 to 0.60 . The simultaneous decrease in the free VSS concentration and in the VSS/TSS concentration suggests loss of bacteria in the CAS bioreactor. The decrease in HRT from $18 \mathrm{~h}$ to $12 \mathrm{~h}$ was associated with an increase in the OLR from $2.1 \mathrm{~kg}$ COD $\cdot \mathrm{m}^{-3} \cdot \mathrm{d}^{-1}$ to $3.2 \mathrm{~kg}$ CoD $\cdot \mathrm{m}^{-3} \cdot \mathrm{d}^{-1}$. The decrease in free TSS and in free VSS showed that the biomass in the CAS could not handle the operating conditions. These results suggest hybrid technologies are more efficient for PW treatment at reduced HRT.

The results of biofilm quantification indicated significant growth of biofilm on all the surfaces (internal and external) of the Kaldnes ${ }^{\circledR}$ rings in the FBHBR (Figure 4). After drying, biofilm weight was approximately $3.26 \mathrm{mg}$ per carrier. In the FBHBR, $10 \mathrm{~L}$ of raw packing was inserted corresponding to a total of 10,800 rings. The total weight of 
the biofilm was $35.2 \mathrm{~g}$, corresponding to an average biofilm concentration of $1.17 \mathrm{g.L} \mathrm{L}^{-}$ 1. With an average free biomass concentration of $2.75 \mathrm{~g}^{-\mathrm{L}^{-1}}$, the total biomass concentration was approximately $3.92 \mathrm{~g} \cdot \mathrm{LL}^{-1}$. The biofilm thus contributed up to $30 \%$ of the total biomass in the FBHBR. As the overall performance of a bioreactor is proportional to the concentration of biomass, the biofilm increased the treatment capacity of the FBHBR. It has been reported that biofilm adhesion depends on operational conditions such as biofilm age, concentrations of nutrients, concentrations of suspended cells, $\mathrm{pH}$, surface roughness of the packing material, and fluid velocity [40]. Thus, the presence of a significant biofilm seems to indicate that the operational conditions were satisfactory for biofilm growth in the FBHBR. Biofilms provide greater resistance to toxic compounds than free biomass. In biofilms, microorganisms secrete an extracellular matrix to enable them to attach to the bedding material. This extracellular matrix tends to increase the diffusion barrier and slow down the transfer of toxic compounds in the biofilm [26]. This process is advantageous in the treatment of an industrial wastewater such as PW. 


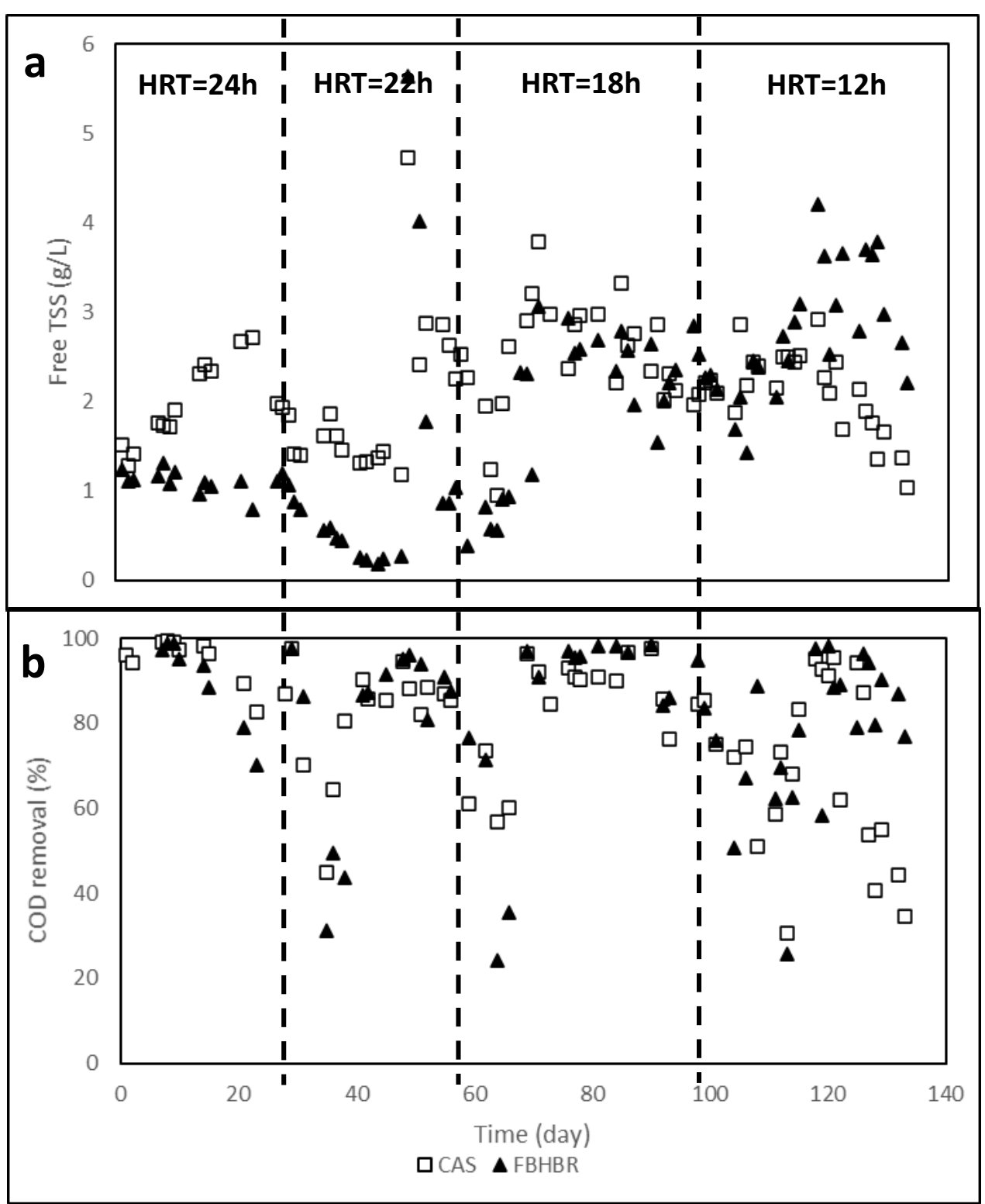

Figure 2. Changes in free TSS concentrations (a) and COD removal efficiencies (b) in the CAS bioreactor (square symbols) and in the FBHBR (black triangles 


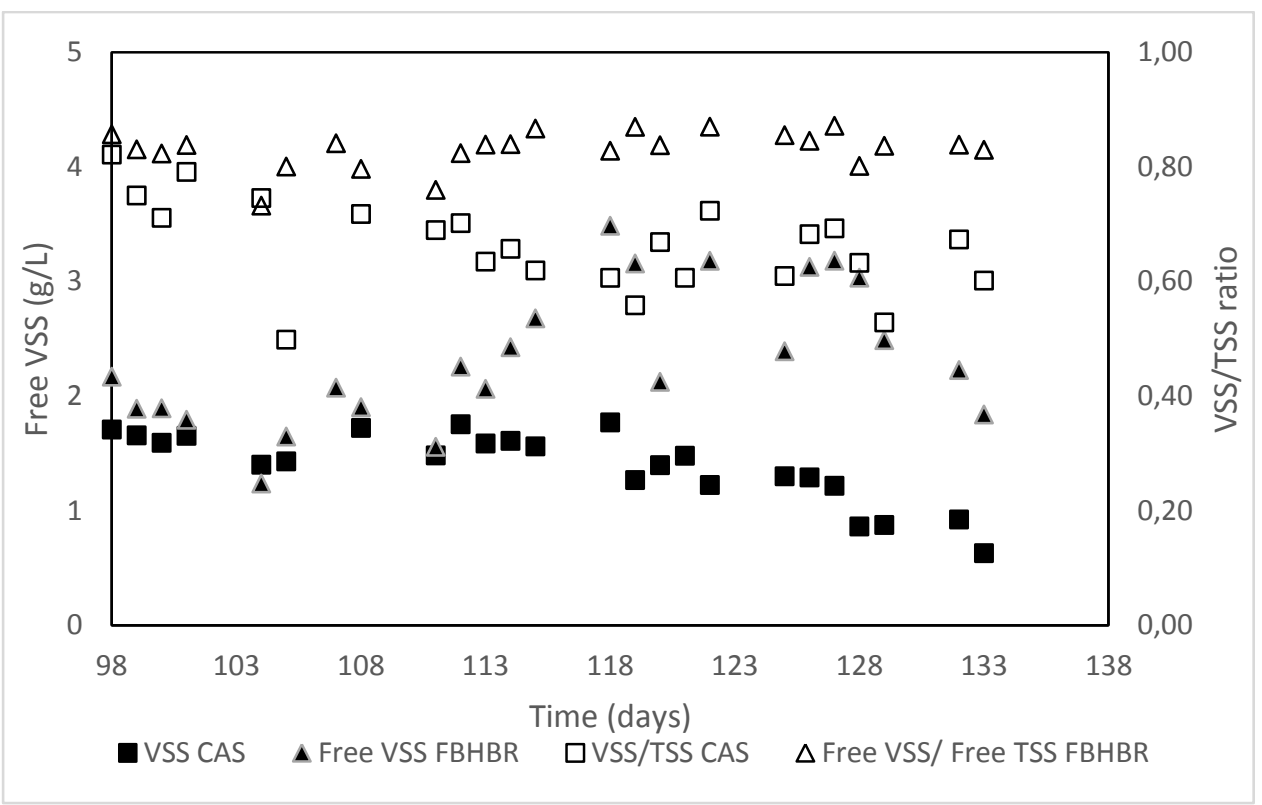

Figure 3. Changes in VSS concentrations and TSS/VSS at the end of the operation

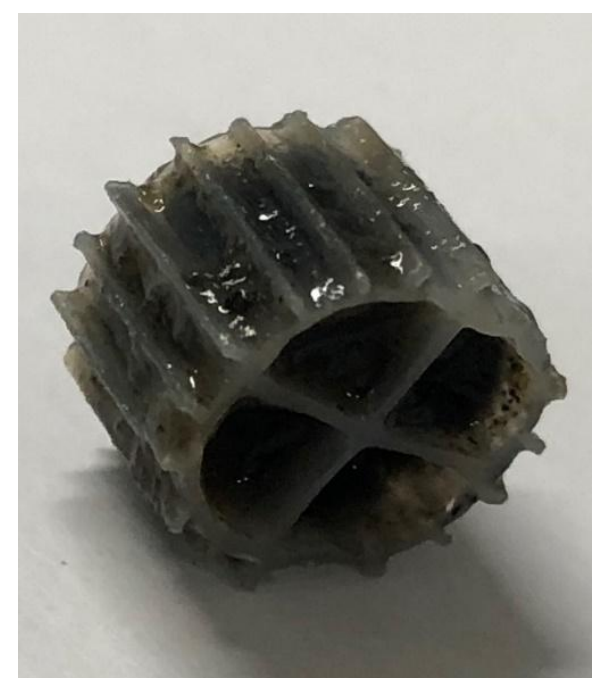

Figure 4. Growth of cells on the packing material in the FBHBR 

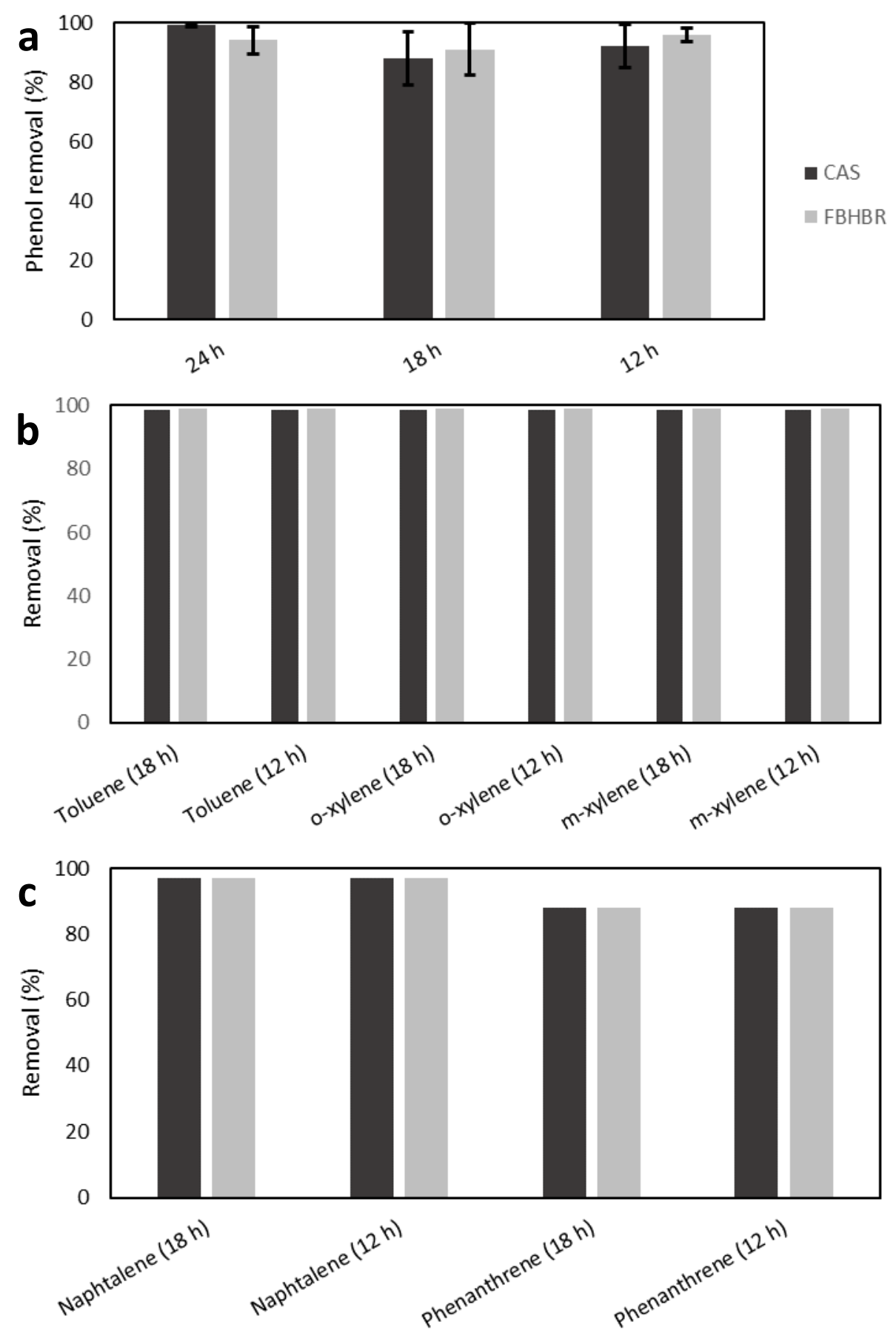

Figure 5. Removal efficiency of (a) phenol, (b) volatile organic compounds, and (c) PAHs in the two reactors at different stages of the process operation 


\subsection{Pollutant removal performance}

\subsubsection{Chemical oxygen demand (COD) removal}

Results concerning the COD removal efficiency for both the CAS reactor and the FBHBR are shown in Figure 2b. COD removal efficiencies remained high (80-99\%) for an HRT of 24, 22 and $18 \mathrm{~h}$. The same behavior was observed in the CAS and FBHBR. After biomass acclimation, COD removal efficiency reached more than $95 \%$ (day 0-28) due to sufficient contact time between the acclimated biomass and the wastewater. After each decrease in the HRT, removal efficiency decreased (down to $30 \%$ in the CAS reactor and to $25 \%$ in the FBHBR) as the experimental conditions changed. Yet, after a few days, COD removal efficiencies again reached steady high values $(80-99 \%)$. It is worth noting that stabilization took longer at each decrease in the HRT. Nonetheless, the biomass microorganisms proved their ability to adapt to more difficult conditions under shorter HRTs. At $12 \mathrm{~h} \mathrm{HRT}$, the CAS reactor was not able to maintain high removal efficiency and decreased continuously to finally reach only $34 \%$ of COD removal when the experiments were stopped. In the FBHBR, removal remained high (77-99\%) after the stabilization phase, certainly due to the greater quantity and higher diversity of biomass. The decrease in VSS linked to the loss of bacteria and to the absence of a biofilm in the CAS reactor may have caused this significant drop in removal efficiency. Dong et al. [30] studied the influence of an $\mathrm{HRT}$ reduction in a MBBR to treat oilfield wastewater. At an HRT of $36 \mathrm{~h}$ to $10 \mathrm{~h}$, corresponding to an increase in the organic loading rate (OLR) of $1.17 \mathrm{~kg}$ COD $\cdot \mathrm{m}^{-3} \cdot \mathrm{d}^{-1}$ to $4.21 \mathrm{~kg} \mathrm{COD}_{\mathrm{m}} \mathrm{m}^{-3} \cdot \mathrm{d}^{-1}$, these authors observed high removal efficiencies with long HRTs. When the HRT was reduced, they noted that moving bed biofilm reactors performed better than CAS reactors under the same operating conditions, confirming 
that biofilm bioreactors resist loading shocks better. Further, the good performances were linked to the presence of biofilms on the surface of the carriers.

\subsubsection{Removal of pollutants}

Phenol removal efficiency at each equilibrium stage is shown in Figure $5 \mathrm{a}$ for each bioreactor. High removal efficiencies were observed whatever the period. Several measurements were made at the end of each stage to calculate the overall phenol removal efficiency. In the CAS bioreactor, this value reached $99 \%, 88 \%$ and $92 \%$ at an HRT of $24 \mathrm{~h}, 18 \mathrm{~h}$, and $12 \mathrm{~h}$, respectively. These high values suggest biomass acclimation in the CAS bioreactor was satisfactory. The slight decrease observed at an HRT of $18 \mathrm{~h}$ was probably due to the bulking phenomenon and the addition of fresh sludge: as the new bacteria added in the bioreactor were not acclimated to phenol, there was a drop in phenol removal efficiency. In the FBHBR, overall phenol removal efficiencies were $94 \%, 91 \%$ and $96 \%$ at an HRT of $24 \mathrm{~h}, 18 \mathrm{~h}$ and $12 \mathrm{~h}$, respectively. Here again, the high values confirmed the satisfactory acclimation of the biomass in the FBHBR. Degradation of phenolic compounds from heavy oil wastewater was studied by Tong et al. [19]. Their bioreactor, which consisted in a conventional activated sludge process coupled with an immobilized biological filter, was able to completely remove phenolic compounds from the wastewater, confirming the ability of biological technologies to completely remove phenol from PW. Equivalent efficiency can also be obtained with more compact processes, as shown in the present study.

Figure $5 \mathrm{~b}$ shows the removal efficiency of volatile organic compounds (VOCs) (toluene, o-xylene, m-xylene) at different stages of process operation. High removal efficiencies (over 99\%) were observed for toluene, o-xylene, and m-xylene at each stage of the process, as indicated by the absence of these compounds in the outlet 
water. The high volatility of these compounds coupled with air stripping caused by the aeration are probably the main VOC removal mechanisms. Fatone et al. [41] documented the fate of VOCs in CAS reactors and membrane bioreactors and showed that volatilization and air stripping were the main removal mechanisms in both CAS and membrane bioreactors. Due to high aeration efficiency in both the CAS bioreactor and FBHBR, volatilization most probably explains a large proportion of VOC removal.

Figure $5 \mathrm{c}$ shows $\mathrm{PAH}$ removal efficiencies in the two bioreactors. Here again, high removal efficiencies were obtained in both bioreactors. Naphthalene removal efficiency was more than $97 \%$ and phenanthrene removal efficiency more than $88 \%$. In their study, Dong et al. [30] obtained $79 \%$ of removal efficiency for both naphthalene and phenanthrene. Removal mechanisms may include bacterial degradation but also adsorption on biomass (biofilm and free sludge) and volatilization.

\subsection{Ecotoxicity measurements}

Water toxicity was assessed at HRTs of $18 \mathrm{~h}$ and $12 \mathrm{~h}$ in both the CAS bioreactor and the FBHBR. Results expressed as EC50 are listed in Table 5. A minimum EC50 indicates the tested sample is highly toxic for the microorganism, whereas a maximum EC50 indicates the sample is not toxic for the microorganism. As the sensitivity of each microorganism to the inlet water can vary, it was important to conduct ecotoxicity tests using several common microorganisms. In this study, the sensitivity of Daphnia magna, Pseudokirchneriella subcapitata (freshwater algae), Brachionus calyciflorus (rotifer) and Vibrio fischeri (i.e. Microtox test) to the inlet water 
were tested. Results showed that the inlet water was highly toxic to freshwater algae and Brachionus calyciflorus and slightly toxic to Daphnia magna and Vibrio fischeri. These results highlight different degrees of sensitivity among organisms, Brachionus calyciflorus and Pseudokirchneriella subcapitata being more sensitive than Vibrio fischeri and Daphnia magna. After treatment, no toxicity remained for Daphnia magna and Vibrio fischeri, and a major reduction in toxicity for Brachionus calyciflorus and Pseudokirchneriella subcapitata, was observed in both bioreactors. The absence of toxicity was due to the elimination of pollutants in both bioreactors and provides evidence that biological treatments such as CAS or FBHBR can efficiently eliminate the toxicity of a synthetic PW. These results confirm those of by Sambusiti et al. [21].

Table 5. Ecotoxicity measurements of inlet water and outlet water in the CAS reactor and FBHBR expressed as EC50 (\%) (NT Non-toxic)

\begin{tabular}{cccccc}
\hline Microorganism & Inlet & $\begin{array}{c}\text { HRT }=18 \mathbf{~ h} \\
\text { Outlet } \\
\text { CAS }\end{array}$ & $\begin{array}{c}\text { Hotlet } \\
\text { FBHBR }\end{array}$ & $\begin{array}{c}\text { Outlet } \\
\text { CAS }\end{array}$ & $\begin{array}{c}\text { Outlet } \\
\text { FBHBR }\end{array}$ \\
\hline $\begin{array}{c}\text { Daphnia magna } \\
\text { (48 h) }\end{array}$ & 61.3 & 89 & NT & NT & NT \\
$\begin{array}{c}\text { Rotifers (i.e. } \\
\text { Brachionus } \\
\text { calyciflorus) }\end{array}$ & 12.5 & $>90$ & $>90$ & 43.6 & $>90$ \\
$\begin{array}{c}\text { Freshwater algae } \\
\text { (i.e. }\end{array}$ & & & & & \\
$\begin{array}{c}\text { Pseudokirchneriella } \\
\text { subcapitata) }\end{array}$ & 15.1 & $>90$ & 70 & $>90$ & $>90$ \\
$\begin{array}{c}\text { Microtox test (i.e. } \\
\text { Vibrio fischeri) }\end{array}$ & $>80$ & 59.8 & NT & $>80$ & NT \\
\hline
\end{tabular}

3.4 Assessment of bacterial populations

3.4.1 Changes in microbial diversity 
Ten samples were analyzed to obtain an overview of the bacterial population in the two bioreactors under each HRT. Sequencing of the samples generated a total number of $295 \mathrm{k}$ sequences. The number of operational taxonomic units (OTU), determined by a minimum of $97 \%$ similarity with referenced units, was 1,058 in the inoculum. When the bioreactors were operated at an HRT of $24 \mathrm{~h}$, the number of OTUs was 728 for CAS suspended flocs, 804 for FBHBR suspended flocs, and 807 for FBHBR biofilm. When the HRT was reduced to $18 \mathrm{~h}$, the number of OTUs increased to 834 for CAS suspended flocs, to 1,099 for FBHBR suspended flocs and to 1,047 for FBHBR biofilm. Finally, at the end of the test program at an HRT of $12 \mathrm{~h}$, the number of OTUs was 498 for CAS suspended flocs, 770 for FBHBR suspended flocs, and 944 for FBHBR biofilm. It is worth noting that the number of OTUs was higher in the FBHBR (in both suspended flocs and biofilm) than in the CAS bioreactor, suggesting higher richness in both suspended flocs and biofilm in the FBHBR. In addition, the number of OTUs was always higher in the biofilm than in the suspended flocs in the FBHBR. This highlights one of the main advantages of biofilm over suspended flocs. This high diversity could play a major role during treatment of synthetic oilfield PW and explain the significant performance of the FBHBR under low HRTs. These results are consistent with those obtained by Huang et al. [31] in an integrated fixed-film activated sludge system treating oil sands process-affected water.

Figure 6a shows the changes in the Shannon-Weaver index in the bioreactors. The Shannon-Weaver index of the inoculum from the WWTP was 4.94. This high value indicates a diverse bacterial population, typical of municipal treatment plants. Changes in diversity in the CAS bioreactor points to microbial specialization. Indeed, 
at an HRT of $24 \mathrm{~h}$, the index decreased to 4.27 . This suggests that biomass acclimation depends on the dominance of certain bacterial species. Interestingly, at an HRT of $18 \mathrm{~h}$, the index increased to 5.11 due to the addition of fresh sludge in the CAS bioreactor during the bulking phenomenon. At an HRT of $12 \mathrm{~h}$, the index again decreased to 3.93 , indicating specialization. The specialization in the CAS bioreactor suggests the PW was toxic to some bacterial species and confirms the low resistance of suspended flocs in conventional technologies.

In the FBHBR, diversity remained high in both the biofilm and in the suspended sludge whatever the HRT. At an HRT of $24 \mathrm{~h}$, the Shannon-Weaver index for suspended flocs was 4.8 , and 4.94 for the biofilm in the FBHBR. It is also worth noting that the addition of fresh sludge at an HRT of $18 \mathrm{~h}$ increased the Shannon Weaver index of suspended flocs to 4.95 and of the biofilm to 5.53. Finally, at an HRT of $12 \mathrm{~h}$, the Shannon-Weaver index remained high with values of 4.86 for suspended flocs and 4.97 for the biofilm. Diversity in the FBHBR was similar to that of the inoculum. At each stage of the process, the Shannon Weaver index of the biofilm was higher than that of the free sludge. This resulted in higher bacterial diversity in the biofilm than in the free sludge. Because of this particular growth mechanism, biofilms present significant heterogeneity. The oxygen and nutrient gradients in the biofilm enable slow growing microorganisms to develop, thereby further increasing biofilm diversity [26].

Figure $6 \mathrm{~b}$ shows changes in the Simpson's reciprocal index in the two bioreactors. Simpson's index quantifies the diversity in a sample, considering the number of species present and the abundance of each. This index measures the probability that two randomly selected individuals from a sample belong to the same species. Its value ranges from 0 (infinite diversity) to 1 (no diversity). The reciprocal index can 
also be presented for better visibility. In this case, a value of 1 indicates absence of diversity and 0 represents infinite diversity. At an HRT of $24 \mathrm{~h}$, values of the Simpson reciprocal indices were 12.1 for suspended flocs in the CAS bioreactor, 44.6 for suspended flocs in the FBHBR and 55.1 for biofilm in the FBHBR. At an HRT of $18 \mathrm{~h}$ and after the addition of fresh sludge, the Simpson reciprocal indices were 47.5 for suspended flocs in the CAS bioreactor, 28.4 and 92.5 for suspended flocs and biofilm, respectively, in the FBHBR. At the shortest HRT (12 h), values were 21.52 for suspended flocs in the CAS bioreactor, and respectively, 40.41 and 40.73 for suspended flocs and biofilm in the FBHBR. These results show that the diversity of microbial species was higher in the biofilm than in the suspended flocs in both reactors. At an HRT of $18 \mathrm{~h}$, the Simpson reciprocal index of suspended flocs in the CAS bioreactor was surprisingly higher, certainly due to the addition of fresh sludge in both bioreactors.

Taken together, the number of OTUs, the Shannon Weaver index and the Simpson reciprocal index suggest that microbial species diversity is higher in the FBHBR than in the CAS bioreactor. In particular, diversity of the biofilm was significantly higher than that of the suspended flocs in the FBHBR. This underlines one of the main advantages of biofilm-based hybrid processes over conventional processes. Different behaviors were observed in the two bioreactors. While in the FBHBR, biomass diversity remained high due to the presence of the biofilm, specialization occurred in the CAS bioreactor, i.e. some bacterial species became much more dominant in the CAS bioreactor. It is worth noting that the sludge retention time (SRT) governed biomass diversity in the CAS bioreactor. In this case, an SRT of 20 days limited the biomass diversity in the CAS bioreactor to bacteria that require less than 20 days to develop. Conversely, in the FBHBR, the retention time of the biofilm is much longer 
(infinite if no detachment occurs). In contrast to the CAS bioreactor, this particularity enables the development of bacteria in the biofilm that require more than 20 days to develop. Slow-growing bacteria can consequently develop and increase microbial species diversity in the FBHBR to a greater extent than in the CAS bioreactor. High Shannon indices in FBHBR treating oil sands process-affected water were also reported by Huang et al. [31]. In their study, the Shannon weaver indices of biofilm were higher than those of suspended sludge, testifying to higher diversity. High microbial species diversity in the FBHBR should have advantages including better biomass acclimation, as specific pollutant-degrading bacteria could grow thanks to the biofilm. In turn, this could increase the resistance of the biomass to loading shocks in the presence of toxic inhibitor compounds. 


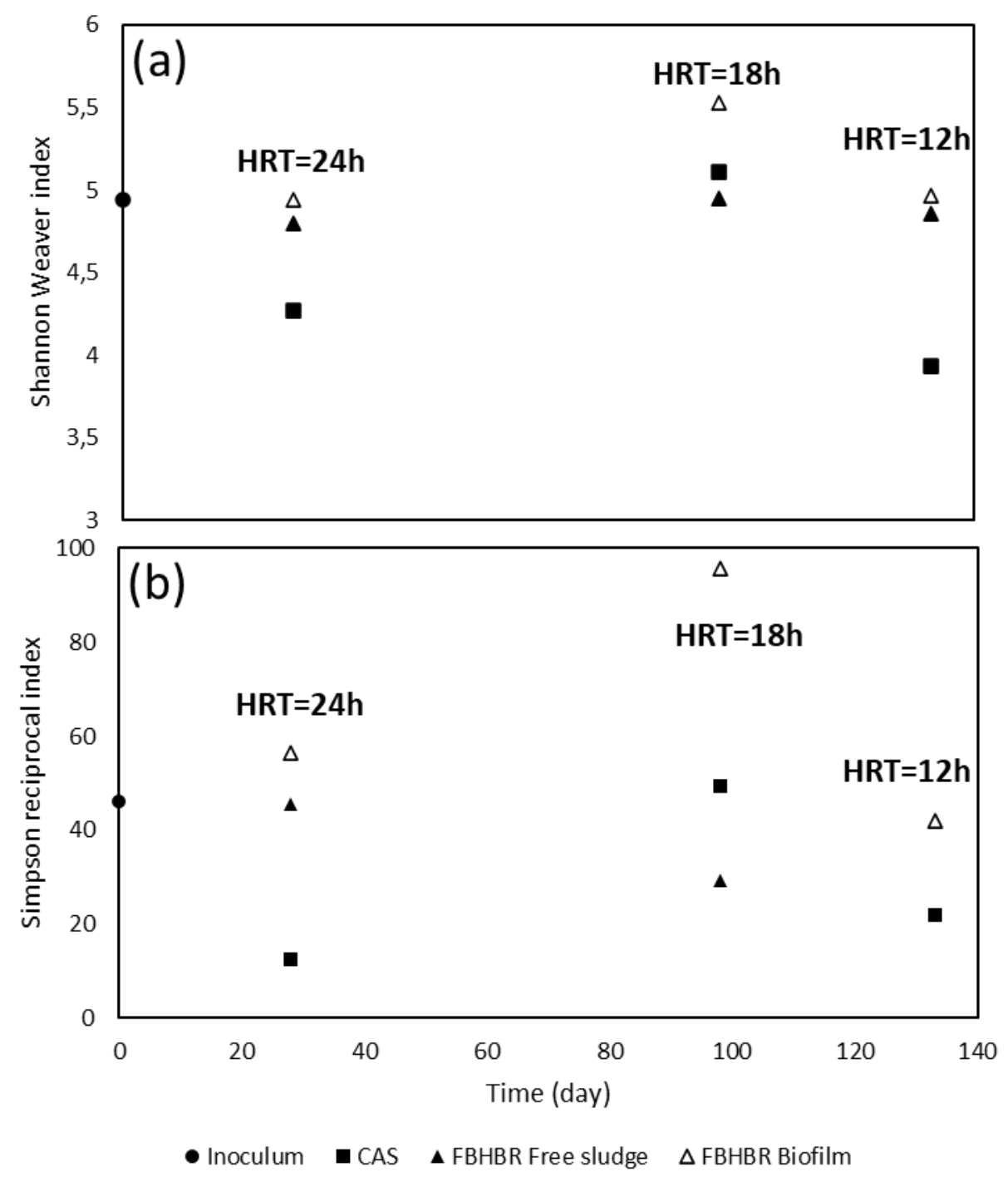

Figure 6. Changes in the Shannon Weaver index (a) and in the Simpson reciprocal index (b) in the two bioreactors

3.4.2 Bacterial classification at the genus level

Figure 7 shows the results of 16S rRNA analysis of the bacterial communities at the genus level in the two bioreactors. The sequences shown represent a minimum of $1 \%$ of their total sequences. In terms of genus, the two bioreactors exhibited different behaviors. In our processes, the inoculum (urban wastewater activated sludge) was fed with a synthetic substrate containing molecules that are characteristic of a PW, and these are very different from those in urban wastewaters and the operating 
conditions are also very different. This led to a marked change in the distribution of bacterial species in the two bioreactors. A list of all genera representing more than $1 \%$ is provided in supplementary material.

In the FBHBR, similar bacterial populations were observed in the free sludge and the biofilm due to strong mutual interactions. Results revealed marked differences between CAS free sludge and FBHBR biofilm at HRTs of $24 \mathrm{~h}$ and $12 \mathrm{~h}$. This suggests that different mechanisms are responsible for bacterial fluctuations in the two bioreactors. As the same effluent was treated in the bioreactors at the same HRT, only the bioreactor configuration can have had an impact on the bacterial populations. Interestingly, the difference between free sludge and biofilm in the FBHBR at an HRT of $24 \mathrm{~h}$ and $12 \mathrm{~h}$ was far smaller. The similarity between the two bacterial populations suggests that biofilm detachment determined the bacterial population in the FBHBR.

Interesting changes in populations were observed at the end of the process (HRT of $12 \mathrm{~h})$. In the CAS bioreactor, six species were found to be dominant: Saprospiraceae sp., Rheinhemera sp., Elstera sp. Cloacibacterium sp. BD7-3 sp. and Brevundimonas sp. (corresponding to $53 \%$ of the sequences). In the suspended flocs in the FBHBR, four species represented more than $4 \%$ of the total sequences, Saprospiraceae sp. Roseivivax sp., Rheinemera sp. and HOC-36 sp. (corresponding to $26 \%$ of the total sequences), whereas in the biofilm, only three species, Saprospiraceae sp., Roseivivax sp., and Rheinheimera sp. corresponded to $21 \%$ of the total sequences. This indicates that the number of non-dominant species was higher in the FBHBR than in the CAS bioreactor and consequently, that diversity was higher in the FBHBR than in the CAS bioreactor. In the CAS bioreactor, Brevundimonas sp. appeared to be dominant. In the FBHBR, suspended flocs and biofilm were colonized by 
Roseivivax $s p$. These bacteria have been reported to be hydrocarbon degrading bacteria [42], [43]. This suggests that the biomass was properly acclimated to the synthetic effluent containing hydrocarbons.

To summarize, bigger changes in bacterial populations were observed in the FBHBR than in the CAS bioreactor. At low HRT (i.e. $12 \mathrm{~h}$ ), COD removal performances were much better in the FBHBR than in the CAS bioreactor. This suggests that satisfactory performances could be obtained in a more compact process, which is a key to offshore implementation. Microbial analyses also revealed higher diversity in the FBHBR, which could lead to better robustness and to better ability to degrade specific pollutants in the FBHBR. 


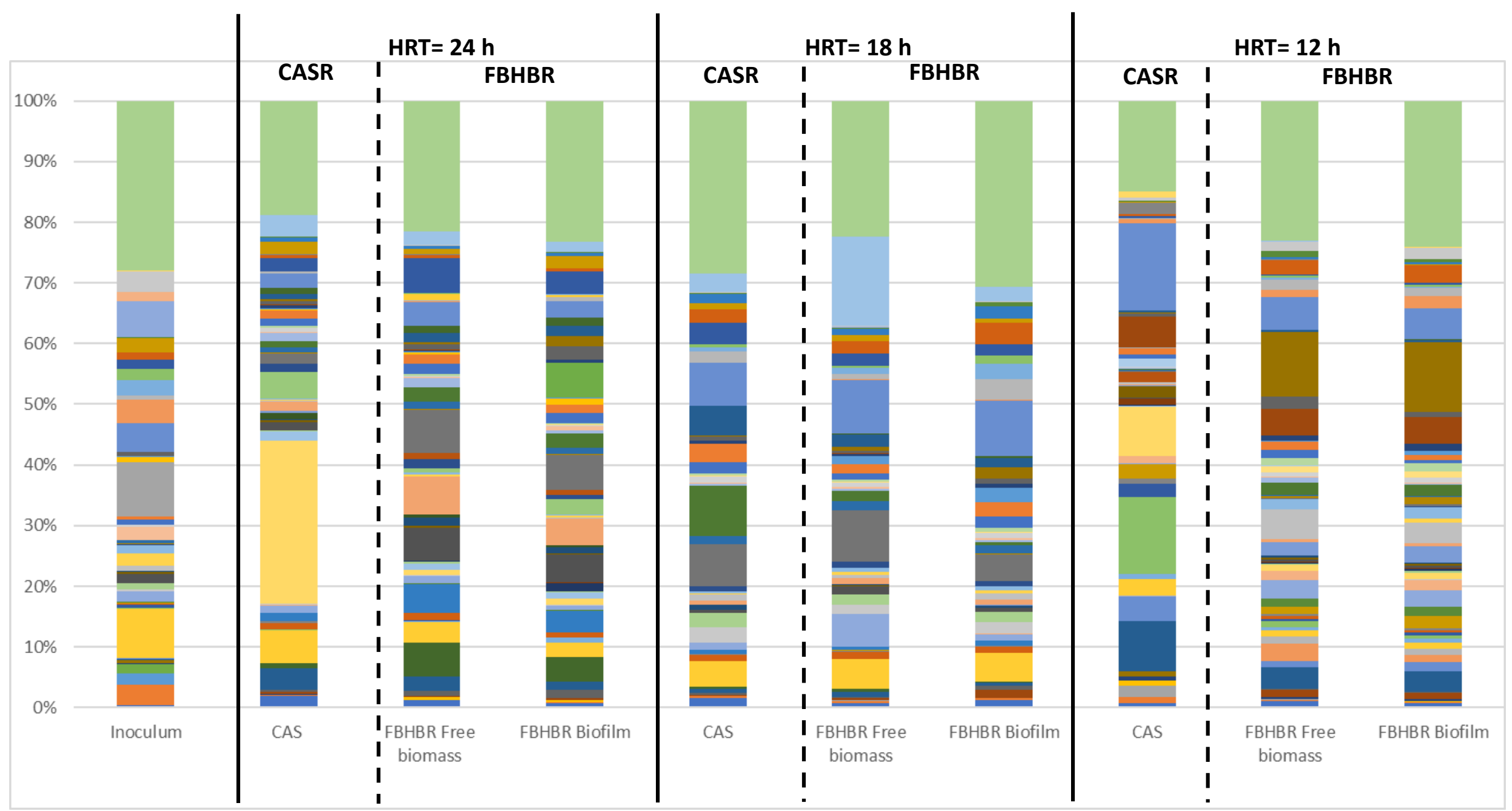




\begin{tabular}{|c|c|}
\hline A4b_unclassified & Acinetobacter \\
\hline Aeromonadaceae_unclassified & Agrobacterium \\
\hline Alishewanella & Alistipes \\
\hline Anaerosinus & Arenimonas \\
\hline Aspromonas & Azoarcus \\
\hline BD7-3_unclassified & Belliella \\
\hline Brevundimonas & a C39 \\
\hline Caldimicrobium & W Chitinophagaceae_unclassified \\
\hline Chryseobacterium & Cloacibacterium \\
\hline Clostridium & Cryomorphaceae_unclassified \\
\hline Cystobacter & Cytophaga \\
\hline Cytophagaceae_unclassified & Cytophagales \\
\hline Dechloromonas & Desulfovibrio \\
\hline Dokdonella & Elstera \\
\hline Emticicia & nemOPS12_unclassified \\
\hline Exiguobacterium & - Fimbriimonas \\
\hline - Flavobacterium & Fusibacter \\
\hline Gemmataceae_undassified & Gluconacetobacter \\
\hline GZKB119_undlassified & Haliscomenobacter \\
\hline 1 HOC36_unclassified & Hydrogenophaga \\
\hline Ignavibacteriaceae_undassified & Wanthinobacterium \\
\hline - Lacibacter & - Legionella \\
\hline Leptothrix & - Luteimonas \\
\hline - Lutibacterium & Methyloversatilis \\
\hline MLE1-12_undassified & Novosphingobium \\
\hline OPB56_unclassified & Owenweeksia \\
\hline Pannonibacter & Phycisphaerales_unclassified \\
\hline E Pirellulaceae_unclassified & E Planctomyces \\
\hline PSB-M-3 & Pseudomonas \\
\hline E Pseudoxanthomonas & Esychrobacter \\
\hline - Reyranella & Eheinheimera \\
\hline Rhodobacter & Roseivivax \\
\hline Rubrivivax & " Runella \\
\hline - Saprospiraceae_unclassified & In-1_unclassified \\
\hline ISC-1-84_unclassified & Wediminitomix \\
\hline = SHA-20_undlassified & W Sinobacteraceae_unclassified \\
\hline Siphonobacter & - SJA-28_unclassified \\
\hline IM1A07_undassified & Eolitalea \\
\hline Wphingobacteriales_undassified & - Syntrophobacteraceae_unclassified \\
\hline Whauera & Wissierella Soehngenia \\
\hline Treponema & Trichococcus \\
\hline Woogloea & Others \\
\hline
\end{tabular}

Figure 7. Microbial population in the two reactors at the genus level: (a) graphical representation and (b) list of species 


\section{Conclusion}

This study focused on the development of hybrid biological reactors for the treatment of oilfield produced water (PW). To face more stringent regulations and the complex composition of PW, the performances of a fixed bed biofilm bioreactor (FBHBR) were assessed and compared to the performances of a conventional activated sludge reactor (CAS reactor). The main conclusions are:

- Under the same operating conditions as those used in a CAS reactor, the addition of a packing material allowed the development of a fixed biofilm. The biofilm concentration at the end of the experiment was $3.26 \mathrm{mg}$ per carrier. This development should enhance the efficiency of FBHBR.

- The reduction in hydraulic retention time (HRT) from $24 \mathrm{~h}$ to $18 \mathrm{~h}$, corresponding to a subsequent increase in organic loading rate from 1.6 to 2.1 $\mathrm{kg}$ COD $\cdot \mathrm{m}^{-3} \cdot \mathrm{d}^{-1}$, did not affect the performance of either the CAS reactor or the FBHBR regarding COD removal efficiencies (> 95\%).

- At HRTs of $24 \mathrm{~h}, 22 \mathrm{~h}$ and $18 \mathrm{~h}$, both the CAS bioreactor and the FBHBR were able to handle loading shocks and return to stable COD removal, evidence for good robustness, considering the marked temporal variability of the composition of produced water. A disturbance to the process (addition of fresh sludge due to a bulking phenomenon) caused no significant reduction in the performances of the processes (there was a slight drop in phenol removal performance but a subsequent return to stability). But under reduced conditions (HRT of $12 \mathrm{~h}$ ), only the FBHBR was able to cope with the loading shock, showing better robustness than the CAS bioreactor. 
- At the lowest HRT (12 h, OLR of $3.2 \mathrm{~kg}$ cold $\left.\cdot \mathrm{m}^{-3} \cdot \mathrm{d}^{-1}\right)$, only the FBHBR was able to maintain high COD removal efficiency. The ability of FBHBR to work under such a low HRT is a key factor for the compactness of treatment processes, especially for offshore applications. The removal of dissolved organic components (phenol, BTEX, and PAH) by both the CAS and the FBHBR was high, indicating good acclimation of the biomass.

- Absence of toxicity in the outlet waters after treatment was achieved by both bioreactors, which was directly linked to the removal of pollutants in the treated effluents.

- Bacterial characterization revealed major differences between the CAS bioreactor and FBHBR. Biomass diversity was higher in the FBHBR than in the CAS bioreactor, particularly in the biofilm. The assessment of the bacterial populations revealed marked similarity between the free biomass and the biofilm in the FBHBR suggesting that the renewal of the free biomass was mainly due to biofilm detachment.

In future work, analyzing the influence of salinity will be of major importance since it can reach high levels in produced water. This paper demonstrated the efficiency of FBHBR. However, the drop in pressure needs to be further investigated to fully confirm the efficiency of the FBHBR since the presence of the packing material caused liquid to flow differently in the FBHBR than in the CAS bioreactor.

\section{References}

[1] L. Aroswoshola et Global Water Intelligence, Produced water market: opportunities in the oil, shale and gas sectors in North America. Oxford, UK: Media Analytics, 2011.

[2] R. Dores, A. Hussain, M. Katebah, et S. S. Adham, "Using Advanced Water Treatment Technologies To Treat Produced Water From The Petroleum Industry », 2012, doi: 10.2118/157108-MS. 
[3] J. A. Veil, M. G. Puder, D. Elcock, et R. J. Redweik Jr., "A white paper describing produced water from production of crude oil, natural gas, and coal bed methane. ", ANL/EA/RP-112631, 821666, févr. 2004. doi: 10.2172/821666.

[4] M. A. Al-Ghouti, M. A. Al-Kaabi, M. Y. Ashfaq, et D. A. Da'na, « Produced water characteristics, treatment and reuse: A review ", J. Water Process Eng., vol. 28, p. 222- 239, avr. 2019, doi: 10.1016/j.jwpe.2019.02.001.

[5] B. Alley, A. Beebe, J. Rodgers, et J. W. Castle, "Chemical and physical characterization of produced waters from conventional and unconventional fossil fuel resources ", Chemosphere, vol. 85, $\mathrm{n}^{\circ} 1$, p. 74- 82, sept. 2011, doi: 10.1016/j.chemosphere.2011.05.043.

[6] J. D. Arthur, L. W. Dillon, et D. J. Drazan, « Management of produced water from oil and gas wells. Working document of the NPC North American Resource Development Study », Paper \#2-17, sept. 2011. Consulté le: nov. 04, 2018. [En ligne]. Disponible sur: https://www.npc.org/Prudent_DevelopmentTopic_Papers/2-17_Management_of_Produced_Water_Paper.pdf.

[7] S. Munirasu, M. A. Haija, et F. Banat, « Use of membrane technology for oil field and refinery produced water treatment-A review », Process Saf. Environ. Prot., vol. 100, p. 183- 202, mars 2016, doi: 10.1016/j.psep.2016.01.010.

[8] Y. Liang, Y. Ning, L. Liao, et B. Yuan, « Special Focus on Produced Water in Oil and Gas Fields ", in Formation Damage During Improved Oil Recovery, Elsevier, 2018, p. 515- 586.

[9] C. E. Clark et J. A. Veil, "Produced water volumes and management practices in the United States. ", ANL/EVS/R-09-1, 1007397, sept. 2009. doi: $10.2172 / 1007397$.

[10] OSPAR Commission, "OSPAR Recommendation 2012/5 for a risk based approach to the management of roduced water discharges from offshore installations ", Decisions, Recommendations \& Agreements, 2012. https://www.ospar.org/convention/agreements (consulté le mai 29, 2018).

[11] J. Zheng, B. Chen, W. Thanyamanta, K. Hawboldt, B. Zhang, et B. Liu, "Offshore produced water management: $A$ review of current practice and challenges in harsh/Arctic environments ", Mar. Pollut. Bull., vol. 104, $\mathrm{n}^{\circ} 1-2$, p. 7- 19, mars 2016, doi: 10.1016/j.marpolbul.2016.01.004.

[12] OSPAR Commission, "Establishment of a list of Predicted No Effect Concentrations (PNECs) for naturally occuring substances in produced water (OSPAR agreement 2014/5) ", Decisions, Recommendations \& Agreements, 2014. https://www.ospar.org/convention/agreements (consulté le mai 29, 2018).

[13] S. Jiménez, M. M. Micó, M. Arnaldos, F. Medina, et S. Contreras, « State of the art of produced water treatment ", Chemosphere, vol. 192, p. 186- 208, févr. 2018, doi: 10.1016/j.chemosphere.2017.10.139.

[14] N. Lusinier, I. Seyssiecq, C. Sambusiti, M. Jacob, N. Lesage, et N. Roche, "Biological Treatments of Oilfield Produced Water: A Comprehensive Review », SPE J., vol. 24, nº 05, p. 2135- 2147, oct. 2019, doi: 10.2118/195677-PA. 
[15] E. A. Sharghi, B. Bonakdarpour, et M. Pakzadeh, «Treatment of hypersaline produced water employing a moderately halophilic bacterial consortium in a membrane bioreactor: Effect of salt concentration on organic removal performance, mixed liquor characteristics and membrane fouling ", Bioresour. Technol., vol. 164, p. 203- 213, juill. 2014, doi: 10.1016/j.biortech.2014.04.099.

[16] E. A. Sharghi et B. Bonakdarpour, "The study of organic removal efficiency and halophilic bacterial mixed liquor characteristics in a membrane bioreactor treating hypersaline produced water at varying organic loading rates ", Bioresour. Technol., vol. 149, p. 486-495, déc. 2013, doi: 10.1016/j.biortech.2013.09.110.

[17] A. Fakhru'I-Razi, A. Pendashteh, Z. Z. Abidin, L. C. Abdullah, D. R. A. Biak, et S. $S$. Madaeni, «Application of membrane-coupled sequencing batch reactor for oilfield produced water recycle and beneficial re-use ", Bioresour. Technol., vol. 101, no 18, p. 6942- 6949, sept. 2010, doi: 10.1016/j.biortech.2010.04.005.

[18] A. R. Pendashteh, L. C. Abdullah, A. Fakhru'I-Razi, S. S. Madaeni, Z. Zainal Abidin, et D. R. Awang Biak, "Evaluation of membrane bioreactor for hypersaline oily wastewater treatment ", Process Saf. Environ. Prot., vol. 90, $\mathrm{n}^{\circ}$ 1, p. 45- 55, janv. 2012, doi: 10.1016/j.psep.2011.07.006.

[19] K. Tong, Y. Zhang, G. Liu, Z. Ye, et P. K. Chu, "Treatment of heavy oil wastewater by a conventional activated sludge process coupled with an immobilized biological filter ", Int. Biodeterior. Biodegrad., vol. 84, p. 65- 71, oct. 2013, doi: 10.1016/j.ibiod.2013.06.002.

[20] G. Di Bella et al., «Performance of membrane bioreactor (MBR) systems for the treatment of shipboard slops: Assessment of hydrocarbon biodegradation and biomass activity under salinity variation », J. Hazard. Mater., vol. 300, p. 765- 778, déc. 2015, doi: 10.1016/j.jhazmat.2015.08.021.

[21] C. Sambusiti et al., "Influence of HRT reduction on pilot scale flat sheet submerged membrane bioreactor (SMBR) performances for Oil\&Gas wastewater treatment ", J. Membr. Sci., vol. 594, p. 117459, janv. 2020, doi: 10.1016/j.memsci.2019.117459.

[22] G. T. Tellez, N. Nirmalakhandan, et J. L. Gardea-Torresdey, "Performance evaluation of an activated sludge system for removing petroleum hydrocarbons from oilfield produced water », Adv. Environ. Res., vol. 6, n 4, p. 455- 470, oct. 2002, doi: 10.1016/S1093-0191(01)00073-9.

[23] C. Grandclément et al., " From the conventional biological wastewater treatment to hybrid processes, the evaluation of organic micropollutant removal: A review ", Water Res., vol. 111, p. 297-317, mars 2017, doi: 10.1016/j.watres.2017.01.005.

[24] H. Ødegaard, B. Rusten, et T. Westrum, "A new moving bed biofilm reactor applications and results ", Water Sci. Technol., vol. 29, n 10-11, p. 157- 165, oct. 1994, doi: 10.2166/wst.1994.0757.

[25] L. Y. Tseng, M. Gonsior, P. Schmitt-Kopplin, W. J. Cooper, P. Pitt, et D. Rosso, "Molecular Characteristics and Differences of Effluent Organic Matter from Parallel Activated Sludge and Integrated Fixed-Film Activated Sludge (IFAS) 
Processes 》, Environ. Sci. Technol., p. 130827102639005, août 2013, doi: 10.1021/es4002482.

[26] Y. Cohen, «Biofiltration - the treatment of fluids by microorganisms immobilized into the filter bedding material: a review », Bioresour. Technol., vol. 77, $\mathrm{n}^{\circ} 3, \mathrm{p}$. 257- 274, mai 2001, doi: 10.1016/S0960-8524(00)00074-2.

[27] H. Machat, C. Boudokhane, N. Roche, et H. Dhaouadi, «Effects of C/N Ratio and DO concentration on Carbon and Nitrogen removals in a Hybrid Biological Reactor ", Biochem. Eng. J., vol. 151, p. 107313, nov. 2019, doi: 10.1016/j.bej.2019.107313.

[28] K. Zerari, I. Seyssieq, D.-E. Akretche, et N. Roche, "Enhancement of oxygen mass transfer coefficients in a hybrid membrane bioreactor: Enhancement of oxygen mass transfer coefficients in a HMBR ", J. Chem. Technol. Biotechnol., vol. 88, nº 6, p. 1007- 1013, juin 2013, doi: 10.1002/jctb.4062.

[29] V. S. Ruys, K. Zerari, I. Seyssiecq, et N. Roche, "Study of Carbonaceous and Nitrogenous Pollutant Removal Efficiencies in a Hybrid Membrane Bioreactor ", J. Chem., vol. 2017, p. 1- 7, 2017, doi: 10.1155/2017/4080847.

[30] Z. Dong, M. Lu, W. Huang, et X. Xu, «Treatment of oilfield wastewater in moving bed biofilm reactors using a novel suspended ceramic biocarrier ", $J$. Hazard. Mater., vol. 196, p. 123-130, nov. 2011, doi: 10.1016/j.jhazmat.2011.09.001.

[31] C. Huang, Y. Shi, Z. Sheng, M. Gamal El-Din, et Y. Liu, «Characterization of microbial communities during start-up of integrated fixed-film activated sludge (IFAS) systems for the treatment of oil sands process-affected water (OSPW) ", Biochem. Eng. J., vol. 122, p. 123-132, juin 2017, doi: 10.1016/j.bej.2017.03.003

[32] A. D. Eaton, American Public Health Association, American Water Works Association, et Water Pollution Control Federation, Éd., Standard methods for the examination of water and wastewater, 21. ed., centennial ed. Washington, DC: American Public Health Assoc, 2005.

[33] S. M. Abtahi et al., "Micropollutants removal in tertiary moving bed biofilm reactors (MBBRs): Contribution of the biofilm and suspended biomass ", Sci. Total Environ., vol. 643, p. 1464-1480, déc. 2018, doi: 10.1016/j.scitotenv.2018.06.303.

[34] AFNOR, «NF ISO 11423-1 (T90-155) of 1997-09-01. Water quality Determination of benzene and some derivatives - Part 1: head-space gas chromatographic method ». 1997.

[35] « DIN ISO 28540 of 2014-05-01. Water Quality - Determination of 16 Polycyclic Aromatic Hydrocarbons (PAH) in Water - Method Using Gas Chromatography with Mass Spectrometric Detection (GC-MS) (ISO 28540:2011). » .

[36] AFNOR, «NF EN ISO 11348-3 (T90-320-3) of 2009-02-01. Water quality Determination of the inhibitory effect of water samples on the light emission of Vibrio fischeri (Luminescent bacteria test) - Part 3: method using freeze-dried bacteria. », 2009. 
[37] AFNOR, «NF EN ISO 8692 (T90-304) of 2012-05-01. Water quality - Fresh water algal growth inhibition test with unicellular green algae. », 2012.

[38] AFNOR, «NF EN ISO 6341 (T90-301) of 2012-12-01. Water quality Determination of the inhibition of the mobility of Daphnia magna Straus (Cladocera, Crustacea) - Acute toxicity test. », 2012.

[39] AFNOR, "NF ISO 20666 (T90-334) of 2009-01-01. Water quality Determination of the chronic toxicity to Brachionus calyciflorus in 48 h ». 2009.

[40] M. J. Chen, Z. Zhang, et T. R. Bott, " Effects of operating conditions on the adhesive strength of Pseudomonas fluorescens biofilms in tubes ", Colloids Surf. B Biointerfaces, vol. 43, $\mathrm{n}^{0}$ 2, p. 61-71, juin 2005, doi: 10.1016/j.colsurfb.2005.04.004.

[41] F. Fatone, S. Di Fabio, D. Bolzonella, et F. Cecchi, "Fate of aromatic hydrocarbons in Italian municipal wastewater systems: An overview of wastewater treatment using conventional activated-sludge processes (CASP) and membrane bioreactors (MBRs) », Water Res., vol. 45, n 1, p. 93- 104, janv. 2011, doi: 10.1016/j.watres.2010.08.011.

[42] T. U. Harwati, Y. Kasai, Y. Kodama, D. Susilaningsih, et K. Watanabe, "Characterization of Diverse Hydrocarbon-Degrading Bacteria Isolated from Indonesian Seawater », Microbes Environ., vol. 22, $n^{\circ}$ 4, p. 412- 415, 2007, doi: 10.1264/jsme2.22.412.

[43] X. Wang, X. Wang, M. Liu, L. Zhou, Z. Gu, et J. Zhao, "Bioremediation of marine oil pollution by Brevundimonas diminuta: effect of salinity and nutrients ", Desalination Water Treat., vol. 57, $n^{\circ} 42$, p. 19768- 19775, sept. 2016, doi: 10.1080/19443994.2015.1106984. 